\title{
Screening In vitro Anticancer Activity of Alseodaphne semecarpifolia Nees Stem Bark Extracts against some Cancer Cell lines
}

\author{
Chethankumara Ganadhal Puttaramaiah ${ }^{1}$, Krishna Venkatarangaiah², Nagaraj Kakanahalli ${ }^{3, *}$
}

\section{Chethankumara Ganadhal \\ Puttaramaiah ${ }^{1}$, Krishna Venkatarangaiah ${ }^{2}$, Nagaraj \\ Kakanahalli3,*}

'Research Scholar, Department of PG Studies and Research in Applied Zoology, Kuvempu University, Shivamogga, Karnataka, INDIA.

${ }^{2}$ Professor, Department of PG Studies and Research in Biotechnology, Kuvempu University, Shivamogga, Karnataka, INDIA. ${ }^{3}$ Professor, Department of PG Studies and Research in Applied Zoology, Kuvempu University, Shivamogga, Karnataka, INDIA.

\section{Correspondence}

Nagaraj Kakanahalli

Professor, Department of PG Studies and Research in Applied Zoology, Kuvempu University, Shivamogga, Karnataka, INDIA.

Phone no: +919620485338

E-mail: knagarajv@gmail.com

History

- Submission Date: 21-01-2019;

- Review completed: 30-03-2019.

- Accepted Date: 22-04-2019.

\section{DOI : 10.5530/pj.2019.11.141}

Article Available online http://www.phcogj.com/v11/i5

\section{Copyright}

(C) 2019 Phcogj.Com. This is an openaccess article distributed under the terms of the Creative Commons Attribution 4.0 International license.

\begin{abstract}
Introduction: Cancer is considered as the prime lethal disease that affects different organs of the body. Even with the rapid developments in the medical sciences, there are no proper medicines to cure specific kind of cancer without side effects. The inhibition of tumour cell growth without side effects either by the use herbal or synthetic drugs is considered as an important target in cancer therapy. In traditional medicinal system A. semecarpifolia stem bark is the prime source of herbal drug to treat lymphatic and skin cancers. Objective: The purpose of this study is to evaluate the anticancer potential of $A$. semecarpifolia stem bark extracts against some cancer cell lines. Methods: The in vitro anticancer activity was evaluated against DLA, EAC, HeLa, HepG2 and L929 cell lines by trypan blue dye exclusion assay and SRB assay. Results: The results of the anticancer activity revealed that, when compared to standard drug Cyclophosphamide, SBPEE and SBCE of A. semecarpifolia showed significant anticancer activity against DLA and EAC cell lines, without causing any toxicity to the normal mouse fibroblast cells L929. Whereas, none of the three extracts showed cytotoxicity against HeLa, HepG2 and L929 cell lines. Conclusion: The present study suggested that, SBPEE and SBCE possesses significant cytotoxic activity against DLA and EAC cell lines, which confirms the traditional medicinal claim of $A$. semecarpifolia as a potent anticancer plant against lymphatic and skin cancer.

Key words: Alseodaphne semecarpifolia, Cell lines, Cell viability, Cytotoxicity, Carcinoma, Lymphoma.
\end{abstract}

\section{INTRODUCTION}

Cancer is a disease caused by loss of cell cycle control, in which there is an uncontrolled multiplication of the cells. ${ }^{1}$ It is associated with abnormal and uncontrolled cell growth. It is a significant health problem worldwide, generally due to the lack of early detection methods. It is caused by both external factors (tobacco, chemicals, radiation and infectious organisms) and internal factors (inherited mutations, hormones, immune conditions and mutations that occur from metabolism). One of the prime requirements of cancer chemo preventive agent is elimination of damaged or malignant cells through inhibition of the rapid multiplication of cells or induction of apoptosis with very less or no toxicity to normal cells. ${ }^{2}$ Controlling the rapid multiplication of the cancer cells without affecting the normal cells is a challenging task in the discovery of anticancer compounds.

Medicinal plants are the gift of the nature for the human beings to treat various kinds of cancers without causing side effects. The reason behind using them as a medicine is, they contain numerous phytocomponents of therapeutic value which are synthesised in the plant body at specific physical, chemical and biological stress conditions. Numerous plants continue to play a pivotal role in drug discovery and development and some of which leads for the development of novel drugs. Hence, evaluation of cancer chemo preventive activity of medicinal plant is of utmost importance in drug discovery.

Alseodaphne semecarpifolia is a large evergreen tree belongs to the family Lauraceae. ${ }^{3-6}$ It grows up to 10 15 metres tall. The stem bark is dark and smooth, Leaves are alternate, usually clustered at the end of the branches. ${ }^{3-6}$ Flowers are small, yellowish-green, in lax panicles at the end of the branches and the fruit is ellipsoid, black, $1-2 \mathrm{~cm}$ long, blunt, smooth and seated on thick clavate pedicel. ${ }^{3-6}$ The flowering and fruiting season of this plant is from March to May. It is distributed in peninsular India and Srilanka, A. semecarpifolia is the only species from the genus Alseodaphne, which is found in Srilanka. ${ }^{7}$ In Malabar (Uttarakannada) and Malnad (Shivamogga) regions of Karnataka, it is commonly called as Mase/Mashe and Sehunda. ${ }^{8-11}$ In southern states of India it is also known as, Nelthare in Kannada, Kanaipirandai, Attapattai and Arambamaram in Tamil, Naaramamimidi in Telugu, Phudgus in Marathi and Mulaknaari in Malayalam. ${ }^{12}$

The ethno medicinal survey in the Malnad region of Karnataka revealed that stem bark of this plant is used to treat lymphatic and skin cancers, but there is no sufficient scientific data is available to defend its traditional claim as an anticancer plant. However, scientific investigations on Alseodaphne

Cite this article: Puttaramaiah CG, Venkatarangaiah K, Kakanahalli N. Screening In vitro Anticancer Activity of Alseodaphne semecarpifolia Nees Stem Bark Extracts Against Some Cancer Cell Lines. Pharmacog J. 2019;11(5):884-8. 
species is still rare and they are less explored phytochemically and pharmacologically. ${ }^{12,13}$ Hence, the present study was undertaken to investigate the anticancer property of the stem bark extracts of $A$. semecarpifolia against four human cancer cell lines, such as Dalton's Lymphoma Ascites (DLA), Ehrlich Ascites Carcinoma (EAC), human cervical cancer cell line HeLa, human hepatoma cell line HepG2. The normal mouse fibroblast cell line L929 was also evaluated in comparison with the standard drugs Cyclophosphamide and Adriamycin.

\section{MATERIALS AND METHODS}

\section{Collection and identification of plant sample}

The stem bark of $A$. semecarpifolia Nees was collected from Karigudda, Aaneguli village, Sagara thaluk and Shivamogga district of Karnataka, India. The plant was identified and authenticated by taxonomist Dr. Y. L. Krishnamurthy, Professor, Department of post graduate studies and research in Applied Botany, Kuvempu University and the voucher specimen was maintained in the Kuvempu University herbaria (No. KUBP78).

\section{Preparation and extraction of the sample}

The freshly collected stem bark was washed under running tap water to remove the soil and other dust particles and air dried in the laboratory condition at room temperature for 45 days. The dried stem bark was ground mechanically into fine powder and subjected to sequential soxhlet extraction for $48 \mathrm{~h}$. The extract was concentrated using rotary evaporator and desiccated until further usage.

\section{In vitro cytotoxicity study}

\section{Cell lines}

Dalton's Lymphoma Ascites (DLA) and Ehrlich Ascites Carcinoma (EAC) tumour cells were obtained from Amala Cancer Research Centre, Thrissur, Kerala, India. HeLa, HepG2 and L929 cell lines were obtained from ACTREC, Khargar, Navi Mumbai and they were grown in RPMI 1640 medium containing 10\% FBS and $2 \mathrm{mM} \mathrm{L}$-glutamine. For the present experiment, the cells were inoculated into 96 well microtiter plates in $100 \mu \mathrm{L}$, depending on the doubling time of individual cell lines. After cell inoculation, the microtiter plates were incubated at $37^{\circ} \mathrm{C}$, with $5 \% \mathrm{CO}_{2}, 95 \%$ air and $100 \%$ relative humidity for $24 \mathrm{~h}$ prior to the addition of plant extracts.

\section{Trypan blue dye exclusion assay}

Alseodaphne semecarpifolia stem bark extracts and the standard drug cyclophosphamide were used for in vitro cytotoxicity study by trypan blue dye exclusion assay, against Dalton's Lymphoma Ascites (DLA) and Ehrlich Ascites Carcinoma (EAC) tumour cells.

Trypan blue dye exclusion assay was carried out according to the protocol described by Strober, 1997. ${ }^{14}$ The tumour cells were washed thrice with PBS. Cell viability was determined by trypan blue dye exclusion technique. Viable cell suspension $\left(1 \times 10^{6}\right.$ cells in $\left.0.1 \mathrm{ml}\right)$ was added to tubes containing various concentrations of the plant extracts and standard drug cyclophosphamide and the volume was made up to $1 \mathrm{ml}$ using PBS. Control tube contained only cell suspension. These assay mixtures were incubated for $3 \mathrm{~h}$ at $37^{\circ} \mathrm{C}$. Further cell suspension was mixed with $0.1 \mathrm{ml}$ of $1 \%$ trypan blue and kept for 2 to 3 min and loaded on to a haemocytometer. Dead cells take up the blue colour of trypan blue while live cells do not.

\section{SRB assay}

A. semecarpifolia stem bark extracts and the standard drug adriamycin were used for in vitro cytotoxicity study by SRB assay, against HeLa, HepG2 and L929 cell lines.
SRB assay was carried out according to the protocol described by Vanicha and Kanyawim, 2006. ${ }^{15}$ The stem bark extracts were initially solubilised in DMSO at $100 \mathrm{mg} / \mathrm{ml}$ and diluted to $1 \mathrm{mg} / \mathrm{ml}$ using water and stored frozen prior to use. At the time of extract addition, an aliquot of frozen concentrate $(1 \mathrm{mg} / \mathrm{ml})$ was thawed and diluted to 100 $\mu \mathrm{g} / \mathrm{ml}, 200 \mu \mathrm{g} / \mathrm{ml}, 400 \mu \mathrm{g} / \mathrm{ml}$ and $800 \mu \mathrm{g} / \mathrm{ml}$. Aliquots of $10 \mu \mathrm{l}$ of these different extract dilutions were added to the appropriate microtiter wells containing $90 \mu \mathrm{l}$ of medium, resulting in the required final extract concentrations i.e. $10 \mu \mathrm{g} / \mathrm{ml}, 20 \mu \mathrm{g} / \mathrm{ml}, 40 \mu \mathrm{g} / \mathrm{ml}$ and $80 \mu \mathrm{g} / \mathrm{ml}$.

After the addition of the plant extracts, plates were incubated at standard conditions for $48 \mathrm{~h}$ and assay was terminated by the addition of cold TCA. Cells were fixed in situ by the gentle addition of $50 \mu \mathrm{l}$ of cold 30\% (w/v) TCA (final concentration, 10\% TCA) and incubated for $60 \mathrm{~min}$ at $4^{\circ} \mathrm{C}$. The supernatant was discarded; the plates were washed five times with tap water and air dried. Sulforhodamine B (SRB) solution $(50 \mu \mathrm{l})$ at $0.4 \%(\mathrm{w} / \mathrm{v})$ in $1 \%$ acetic acid was added to each of the wells and plates were incubated for $20 \mathrm{~min}$ at room temperature. After staining, unbound dye was recovered and the residual dye was removed by washing five times with $1 \%$ acetic acid and the plates were air dried. Bound stain was subsequently eluted with $10 \mathrm{mM}$ trizma base and the absorbance was read on plate reader at a wavelength of $540 \mathrm{~nm}$ with 690 $\mathrm{nm}$ reference wavelength.

Percent growth was calculated on a plate-by-plate basis for test wells relative to control wells. Percent growth was expressed as the ratio of average absorbance of the test well to the average absorbance of the control wells $\times 100$. Using the six absorbance measurements [time zero $(\mathrm{Tz})$, control growth $(\mathrm{C})$ and test growth in the presence of drug at the four concentration levels (Ti)], the percentage growth was calculated at each of the drug concentration levels.

\section{RESULTS}

In trypan blue dye exclusion assay, the cytotoxicity study of different extracts showed that, SBPEE at the concentration of $200 \mu \mathrm{g} / \mathrm{ml}$, significantly controlled the growth of cancer cell lines DLA and EAC with $98.33 \pm 1.15$ and $96.33 \pm 3.51 \%$ inhibition respectively. SBCE showed moderate cytotoxic effect with $78.66 \pm 1.52$ and $83.33 \pm 3.21 \%$ of cell death against DLA and EAC cells. Whereas, the cytotoxic effect of SBEE was found to be very less, i.e. $11.66 \pm 2.08$ and $14.33 \pm 2.51 \%$ against DLA and EAC cells respectively (Figures 1 and 2).

The $\mathrm{IC}_{50}$ value of the SBPEE against DLA cells is $48.07 \pm 3.05 \mu \mathrm{g} / \mathrm{ml}$, whereas it is $47.16 \pm 3.51 \mu \mathrm{g} / \mathrm{ml}$ against EAC cells. The $\mathrm{IC}_{50}$ value of the SBCE against DLA cells is $80.64 \pm 1.15 \mu \mathrm{g} / \mathrm{ml}$, whereas it is $86.20 \pm 2.64$

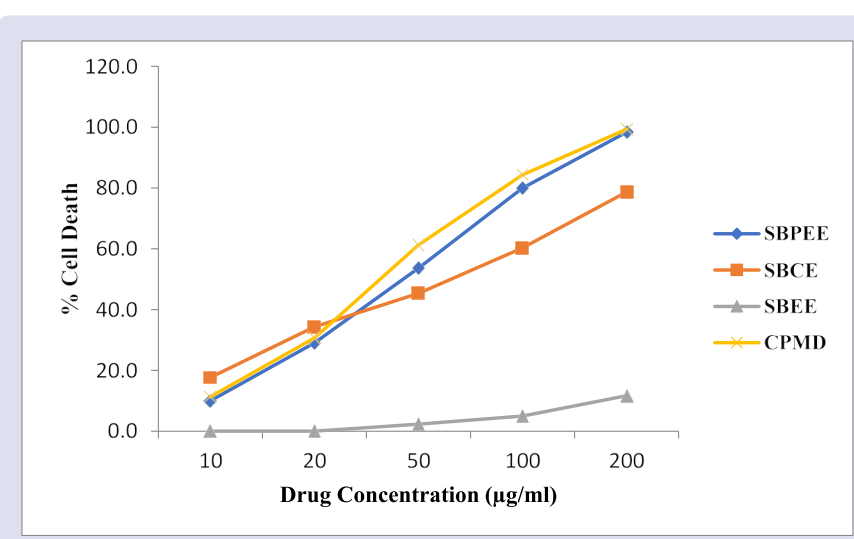

Figure 1: In vitro cytotoxic effect of Alseodaphne semecarpifolia stem bark extracts against DLA cell line. 
$\mu \mathrm{g} / \mathrm{ml}$ against EAC cells. Therefore, the extracts showed toxicity in a dose dependent manner.

In SRB assay, none of the three extracts tested have exerted toxicity against human cervical cancer cell line HeLa, human hepatoma cell line HepG2 and a normal mouse fibroblast cells L929 (Figures 3-5). All the three extracts showed very less control of cell growth against these cell lines when compared to standard drug Adriamycin.

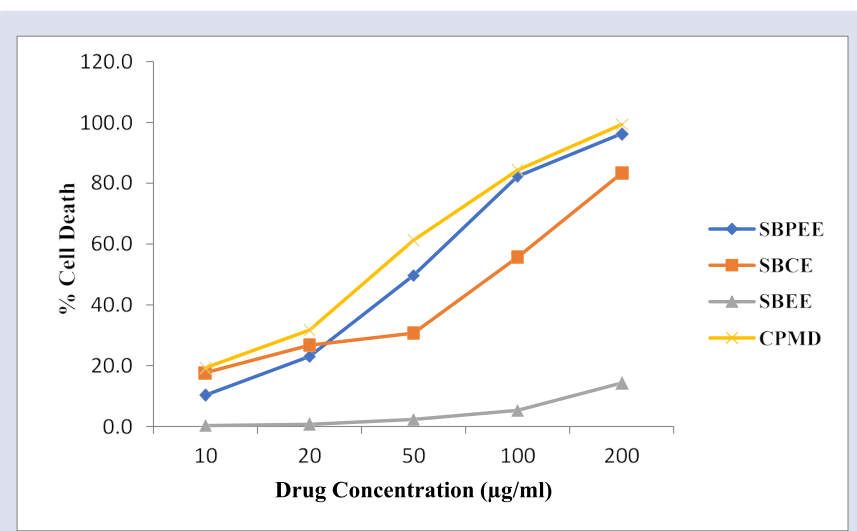

Figure 2: In vitro cytotoxic effect of Alseodaphne semecarpifolia stem bark extracts against EAC cell line.

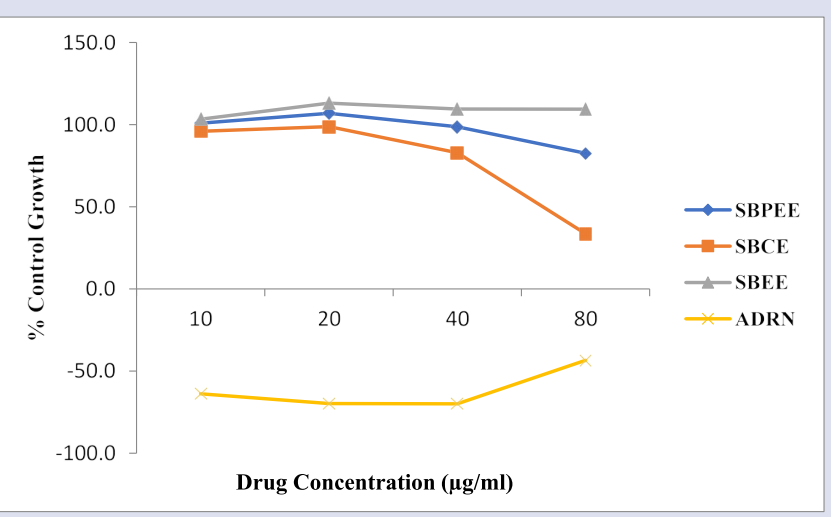

Figure 3: In vitro cytotoxic effect of Alseodaphne semecarpifolia stem bark extracts against HeLa cell line.

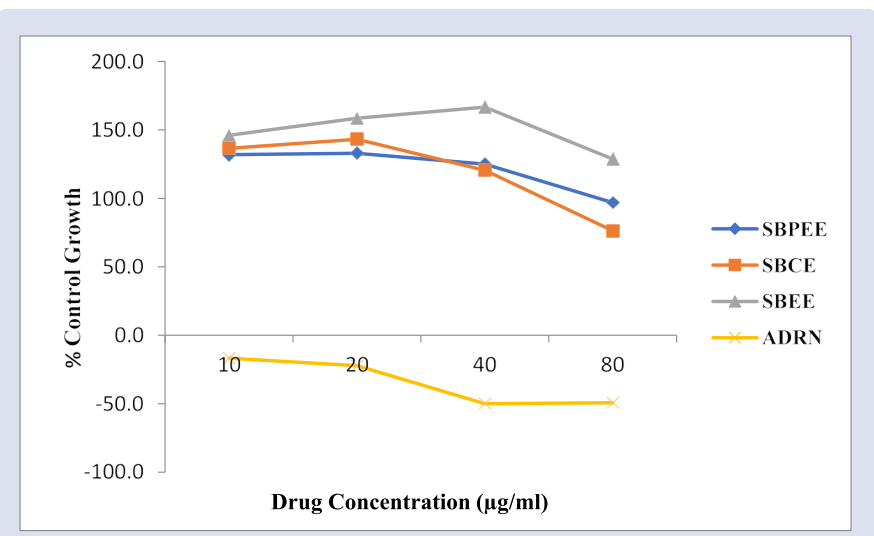

Figure 4: In vitro cytotoxic effect of Alseodaphne semecarpifolia stem bark extracts against HepG2 cell line.

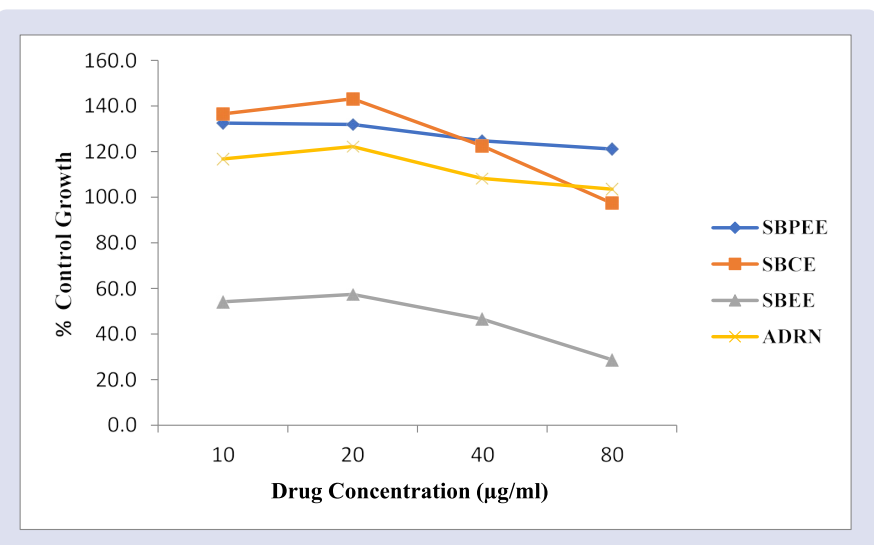

Figure 5: In vitro cytotoxic effect of Alseodaphne semecarpifolia stem bark extracts against L929 cell line.

\section{DISCUSSION}

Anticancer activity is the ability of the natural, synthetic or chemical agents to suppress or prevent carcinogenic progression. Several cytotoxic therapies in ayurveda include herbal remedies as they are the potent medicines in the traditional system and majority of the tumour cells are treated by herbal supplements. One of the best approaches for searching anticancer agents is the selection of medicinal plants based on their ethno medicinal value. ${ }^{16}$

Cancer always need to be diagnosed at its earlier stage, later stages of cancer will be hard to cure. Now a day's surgery, chemotherapy and radiotherapy are the standard methods employed for the treatment of cancer, although they are not fully effective. Efforts have been made to make the cancer treatment more suitable and agreeable, herbal drugs have been employed because they have reported with very low side effects, when compared to synthetic drugs. ${ }^{17}$

The tumour cells used in this study were DLA, EAC, HeLa, HepG2 and L929. Dalton's Lymphoma Ascites is a transplantable, poorly differentiated malignant tumour which appeared originally as lymphocytes in a mouse. ${ }^{18}$ Ehrlich Ascites Tumour is a rapidly growing carcinoma with very aggressive behaviour. ${ }^{19} \mathrm{HeLa}$ is the oldest and most commonly used human cell line. It was derived from cervical cancer cells taken in 1951 from Henrietta Lacks, a patient who died of cancer. The cells taken were cultured and labelled as 'HeLa', in 1953, HeLa cells were the first human cells successfully cloned. ${ }^{20}$ HepG2 is a perpetual cell line which was derived from the liver tissue of a $15 y$ years old Caucasian American male individual with a well differentiated hepatocellular carcinoma. HepG2 cells are the suitable in vitro model system for the study of polarized human hepatocytes. Because of their high degree of morphological and functional differentiation in vitro, HepG2 cells are used as models for the in vitro anticancer studies. ${ }^{21}$ L929 cells are the normal mouse fibroblast cells.

Trypan blue is an essential dye, it will not enter into the cell wall of the plant cells that are grown in the culture..$^{22}$ Trypan blue dye exclusion assay measures the cell viability based on the number of dead cells stained by trypan blue and unstained viable cells. SRB assay measures the cell density based on the measurement of cellular protein content, it is an efficient and highly cost-effective method for screening cytotoxicity.

Alseodaphne semecarpifolia is a potent source of secondary metabolites. ${ }^{23-25}$ Secondary metabolites from several plants exert numerous effects on tumour formation, they protect normal cells of the 
body against adverse effects of anti-cancer therapies. ${ }^{26}$ As Alseodaphne semecapifolia is a potent source of certain secondary metabolites these secondary metabolites may protect normal cells against certain side effects of cancer treatment.

Among three extracts tested, SBPEE showed highest activity indicating its potent cytotoxic property against DLA and EAC tumour cells without affecting the normal mouse fibroblast cells L929. The amount of SBPEE required to cause $50 \%$ cell death against DLA and EAC cells is almost similar to standard drug cyclophosphamide, whereas the amount of SBCE required to cause the $50 \%$ cell death against DLA and EAC cells is twice the value of standard drug cyclophosphamide. None of the three extracts tested have showed toxicity against HeLa, HepG2 and L929 cell lines. Therefore, the results of this study supported the significant in vitro anticancer activity of $A$. semecarpifolia SBPEE and SBCE against solid and ascites tumour cells.

A similar cytotoxicity studies of the Euphorbia neriifolia latex acetone extract against DLA and EAC cells showed $\mathrm{IC}_{50}$ value of 51 and 82 $\mu \mathrm{g} / \mathrm{ml}^{27}$ In the present study A. semecarpifolia SBPEE has highest anticancer activity; it showed $\mathrm{IC}_{50}$ value of $48.07 \pm 3.05 \mu \mathrm{g} / \mathrm{ml}$ and 47.16 $\pm 3.51 \mu \mathrm{g} / \mathrm{ml}$ against DLA and EAC cells respectively. Cytotoxicity study of Thespesia populnea chloroform leaf extract against DLA and EAC cells showed $100 \%$ and $95 \%$ inhibition and Hygrophilla schulli hexane leaf extract showed $94 \%$ and $98 \%$ inhibition against DLA and EAC cells respectively at $200 \mu \mathrm{g} / \mathrm{ml} .{ }^{28}$ In the present study A. semecarpifolia SBPEE showed $98.33 \pm 1.15$ and $96.33 \pm 3.51 \%$ inhibition against DLA and EAC tumour cells respectively at a concentration of $200 \mu \mathrm{g} / \mathrm{ml}$.

\section{CONCLUSION}

The present investigation paves way for pharmacological research in future and for the discovery of new sources of drugs from these phytochemicals. It provides strong evidence that A. semecarpifolia SBPEE and SBCE has in vitro anticancer activity against DLA induced solid tumour and EAC induced ascites tumour cells. Hence, the present study supported the traditional claim of A. semecarpifolia stem bark extract to cure lymphatic and skin cancers. Further validation is required to evaluate the effects of $A$. semecarpifolia SBPEE and SBCE on cell cycle and apoptotic genes.

Even though the anticancer activity of these extracts is fairly weak against HeLa and HepG2 cell lines, the results presented here will prove useful for further research aimed at identifying molecules associated with fewer side effects that may be effective against certain cancers.

\section{ACKNOWLEDGEMENT}

The authors are thankful to DBT, New Delhi, India for providing financial support through DBT-BUILDER project (Order No. BT/ PR9128/INF/22/190/2013, Dated 30/06/2015). We also thank authorities of Kuvempu University, Prof. Ramadasan Kuttan, Research director, Amala Cancer Research Centre, Thrissur, Kerala, India and Dr. Jyoti Kode, Officer incharge, Actrec, Kharghar, Navi Mumbai, India for providing research facilities.

\section{CONFLICTS OF INTEREST}

Authors declare that, there are no conflicts of interest for this study.

\section{ABBREVIATIONS}

ACTREC: Advanced Centre for Treatment, Research and Education in Cancer; ADRN: Adriamycin; CPMD: Cyclophosphamide; DLA: Dalton's Lymphoma Ascites; DMSO: Dimethyl Sulfoxide; EAC: Ehrlich Ascites Carcinoma; FBS: Fetal Bovine Serum; $\mathrm{IC}_{50}$ : Inhibitory Concentration 50; PBS: Phosphate Buffered Saline; RPMI 1640: Roswell Park Memorial Institute 1640 Medium; SBPEE: Stem Bark Petroleum Ether Extract; SBCE: Stem Bark Chloroform Extract; SBEE: Stem Bark Ethanol Extract; SRB: Sulphorhodamine B.

\section{REFERENCES}

1. Sini KR, Haribabu Y, Sajith MS, Surya SK. In-vitro cytotoxic activity of Orthosiphon thymiflorus Roth. leaf extract against Dalton's Lymphoma Ascites cell line. J of Clin and Phar Res. 2012;4(1):917-21.

2. Srivasthava JK, Gupta S. Trocotrienol-rich fraction of palm oil induces cell cycle arrest and apoptosis selectively in human prostate cancer cells. Biochem and Biophy Res Com. 2006;346:447-53.

3. Bhat KG. Flora of South Kanara (Dakshina Kannada and Udupi Districts of Karnataka). K Gopalakrishna Bhat; 2014;59-60.

4. Bhat KG. Flora of Udupi. K Gopalakrishna Bhat; 544.

5. Punekar SA, Lakshminarasimhan P. Flora of Anshi National Park Western GhatsKarnataka. Biospheres Publication; 2011;392.

6. Ingalhalikar S. Flowers of Sahyadri. Corolla Publications; 2007;269

7. Yang JY. A flavonoids study of the family Lauraceae [dissertation]. Canada: The university of British Columbia; 1998

8. Sreenivasa, Kumar. Educational training on ethno veterinary: uses and application of medicinal plants of traditional livestock healers. Gl J of Biosc and Biotec. 2017;6(4):582-7.

9. Harsha VH, Shripathi V, Hegde GR. Ethnoveterinary practices in Uttara Kannada district of Karnataka. Ind J of Trad Know. 2005;4(3):253-8.

10. Chandran MDS, Rao GR, Ramachandra TV. Conservation of fragmented forests in Banavasi range, Sirsi forest devision, Kanara circle. Ener and Wetl res gr, CES, IISC. Sah Cons Ser 50. 2015;1-25.

11. Kumar AKM, Shivaraju HP. A study on traditional knowledge and medicinal applications of the endemic herbal species in the Western Ghats of Shimoga Region, Karnataka, India. Int J of Res in Chem and Env. 2016;6(2):1-13.

12. Charles A, Joseph M, Ramani AV. Phytochemical analysis of Alseodaphne semecarpifolia leaf extract by GC-MS. Asn J of Pharm and Clin Res. 2013;6(4):89-92.

13. Thakur BK, Anthwal A, Rawat DS, Rawat B, Rashmi, Rawat MSM. A review on genus Alseodaphne: Phytochemistry and pharmacology. Min-rev in Org Chem. 2012;9:433-45

14. Strober W. Trypan blue exclusion test of cell viability. Cur Prot in Imm 2001;21(1):A.3B.1-A.3B.2

15. Vanicha $V$, Kanyawim K. Sulforhodamine B colorimetric assay for cytotoxicity screening. Nat Prot. 2006;1:1112-6.

16. Kintzios SE. Terrestrial plant derived anticancer agents and plant species used in anticancer research. Cr Rev on PI Sci. 2006;25:79-113.

17. Subhadradevi V, Christy J, Asok KK, Umamaheshwari M, Sivashanmughan AT Induction of apoptosis and cytotoxic activities of methanolic extract of Careya arborea Roxb bark. Int J of Com Phar. 2010;3(1):1-4.

18. Kleinsmith LJ. Principles of cancer Biology. 4th ed. San Francisco: Pearson Benjamin Cummings; 2007;312.

19. Segura JA, Barbero LG, Marquez J. Ehrlich ascites tumour unbalances spleenic cell population and reduces responsiveness of T. cells to Staphylococcus aureus enterotoxin B stimulation. Imm L. 2000;74:111-5.

20. Hannah L. "Immortality, In vitro: A History of the HeLa Cell Line". In Brodwin, Paul. Biotechnology and culture: bodies, anxieties, ethics. Bloomington: Indiana University Press; 2000;53-74.

21. Moscato, Stefania. Poly(vinyl alcohol)gelatin Hydrogels Cultured with HepG2 Cells as a 3D Model of Hepatocellular Carcinoma: A Morphological Study. J of Fun Bio. 2015;(6):16-32.

22. Patel S, Gheewala N, Suthar A, Shah A. In vitro cytotoxicity activity of Solanum nigrum extract against HeLa Cell Line and Vero Cell Line. Int $\mathrm{J}$ of Phar and Pharm Sc. 2009;1:38-46.

23. Charles A, Stanly LA, Joseph M, Ramani AV. GC-MS analysis of bioactive components on the bark extract of Alseodaphne semecarpifolia Nees (Lauraceae). As J of PI Sc and Res. 2011;1(4):25-32

24. Charles A, Ramani AV. Phytochemical screening and antimicrobial resistance of Alseodaphne semecarpifolia Nees. J of Chem and Pharm Res. 2011;3(5):20511.

25. Ramani AV, Charles A, Stanly LA, Joseph M, Mani C. Novel extraction and phytochemical screening of Alseodaphne semecarpifolia Nees (Lauraceae). Int $\mathrm{J}$ of Phar and Pharm Sci. 2012;4(2):86-7.

26. Korkina L, Kostyuk V. Biotechnologically produced secondary plant metabolites for cancer treatment and prevention. Cur Pharm Biot. 2012;13(1):265-75

27. Chinmayi U, Ajay K, Sathish S. A study on anticancer activity of Euphorbia neriifolia (Milk Hedge) latex. Int J of Ad in Sci, Eng and Tech. 2017;5(2):5-7.

28. Chandran RP, Manju S, Shaji PK, Nair GA, Sukumar B. In-vitro cytotoxic activities of leaf extracts of Thespesia populnea and Hygrophilla schulli against Dalton's Lymphoma Ascites and Ehrlich Ascites Carcinoma cell lines. Aus J of Lu Can Res. 2016;1(2):1007-10. 


\section{GRAPHICAL ABSTRACT}

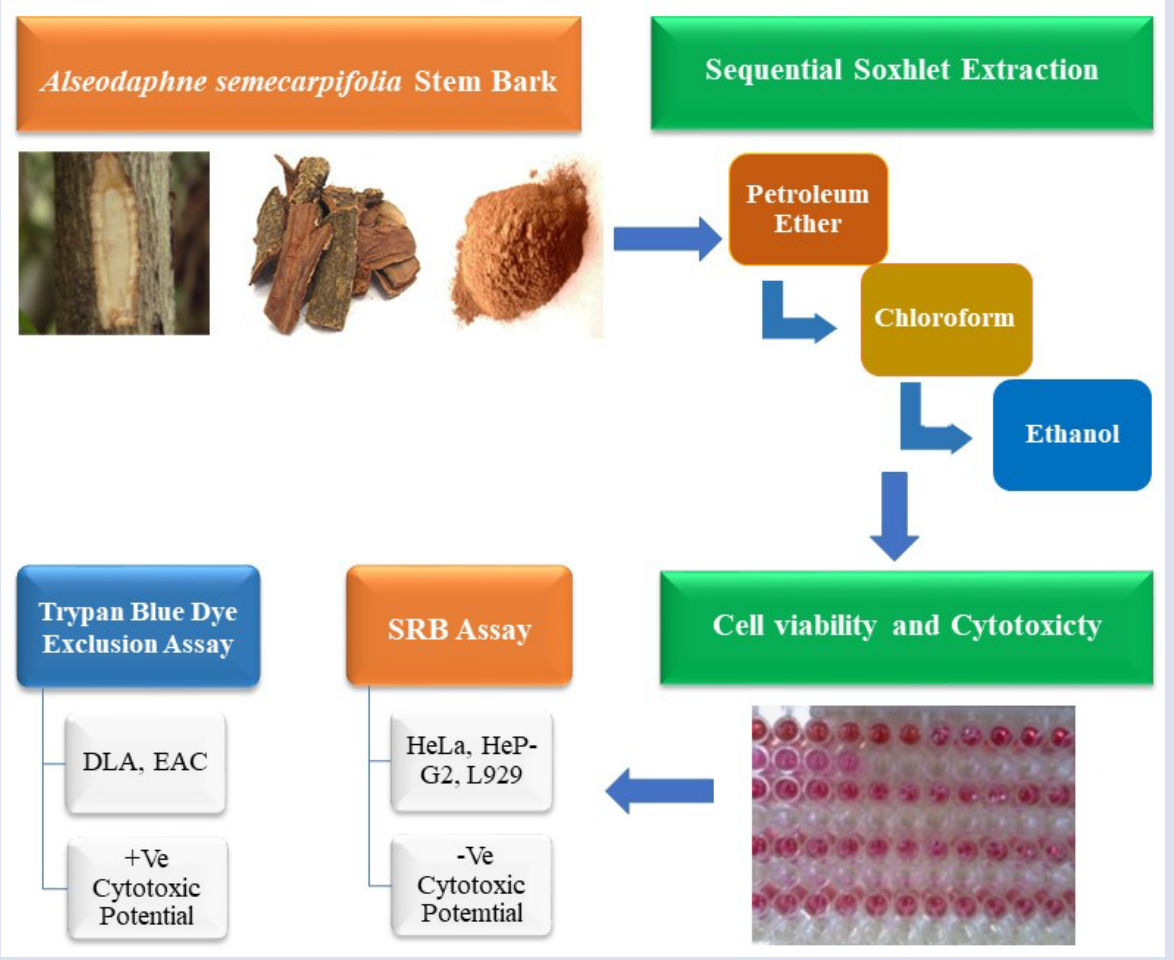

\section{ABOUT AUTHORS}

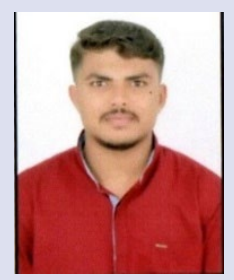

Mr. Chethankumara GP, is Research Scholar in Department of Applied Zoology, Kuvempu University, with three years of research experience in the field of Phytochemistry and Pharmacology. He is working as a Junior Research Fellow in DBT-New Delhi sponsored Builders Project since January 2016 with three research publications.

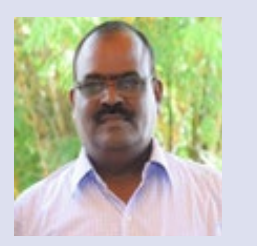

Prof. Krishna V, Department of Biotechnology, Kuvempu University. He has 28 years of teaching and research experience in the field of Plant tissue culture, Phytochemistry and Pharmacology. He has received research grants from DBT, DST and UGC, etc. He has published 190 research papers in international and national peer reviewed journals. He has one patent to his credit.

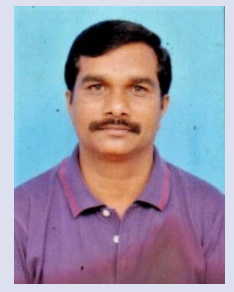

Prof. Nagaraja, Department of Applied Zoology, Kuvempu University. He has 21 years of teaching and research experience in the field of Developmental Neuroscience, Molecular Genetics, Phytochemistry and Pharmacology. He has received research grants from various funding agencies like DBT, DST, UGC and VGST-K-FIST etc.

Cite this article: Puttaramaiah CG, Venkatarangaiah K, Kakanahalli N. Screening In vitro Anticancer Activity of Alseodaphne semecarpifolia Nees Stem Bark Extracts Against Some Cancer Cell Lines. Pharmacog J. 2019;11(5):884-8. 